\title{
THE GHOST IN THE MACHINE
}

\section{Violence in the library.}

\section{BY ANNA NOVITZKY}

$\mathrm{D}$ elilah sank gratefully into her seat. The Reading Room was almost empty: few could be bothered to slog out into the snow when they could call up most of the volumes at home, but Delilah needed the restricted editions and annotations that weren't allowed outside the firewall. She plugged herself into the terminal and waited for the screen to flick up.

The librarian-bot read her signature and greeted her: "Good morning, Dr Samuels! I hope you are well. A Dr Morgan Swift has been asking after you today."

Crap, Delilah thought. I hope you didn't tell her anything.

The bot's animated face fell. "Oh dear," it said, "I hope I have not acted incorrectly. I showed her your marker. Is she not known to you?"

No, thank god. I gave a paper of hers a bad review, and I hear she's on the warpath. I wanted to avoid her.

"My apologies," said the bot forlornly, and then perked up as its script kicked in. "What can I do for you today, Dr Samuels?"

The usual: Boutrand's Etudes d'Alchimie, all commentaries intact.

"Certainly! Do let me know if I can be of any further help."

The bot disappeared, replaced by the familiar text of the Etudes. Delilah opened an annotation window, and flicked away layers of commentary until she reached the original Greek. She settled down to her research.

It was several hours later when the lights went out. In the moments before the backup kicked in, Delilah heard a cry behind her, then felt a searing pain as her plug was knocked out. She shook her head and turned to focus on the blonde woman sitting ruefully in a pile of papers behind her.

"I'm dreadfully sorry," the woman said, "I tripped. Oh, ouch, I must have - sorry."

"Don't worry," Delilah said. She helped the woman pick up her papers, then gingerly plugged herself back in. It needed a bit of wiggling; the socket must have been bruised.

She had not been working for many minutes more when the screen began to flicker; she tapped the plug, but it didn't help. Blackness filled her vision, a gloom infused with loneliness and despair. She shook her head, but the darkness didn't clear. Instead, a noise began at the edge of her hearing - a sibilant whispering that could have been static and

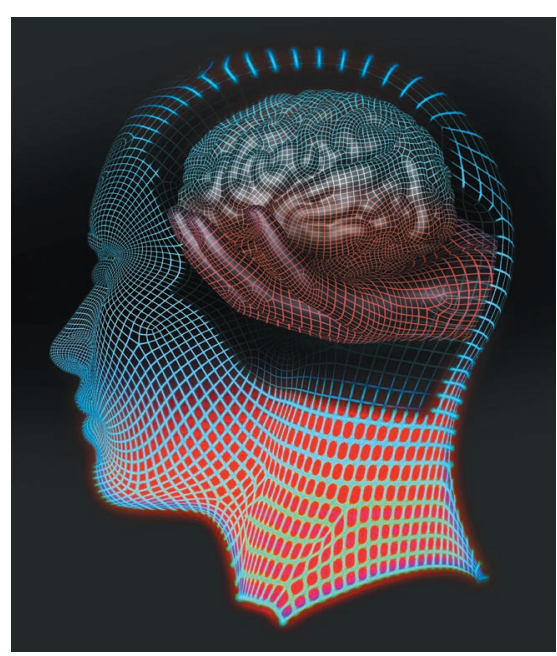

could have been taunting voices. Something crawled across her hand. She twitched away, and felt something else moving behind her. She fought to quell the wave of panic. She wanted to run, or shout, or lash out, but she couldn't. It would get her ...

Wait. What would? The thought struggled out of the fog of her mind and she clutched at it. What would get her? She didn't know, but it was out there, and it was coming, and she had to - no! There was nothing out there. How did she know? Because ... she was in the library. The library! Straining to remain lucid, Delilah focused on the thought. She visualized the Etudes, hard, and it swam into view. Clinging to the edge of the operating system, she thought-screamed, HELP!

The librarian-bot phased in, its lines wavering. She could just make out its slowed-down, protracted voice. "How may I be of assistance, Dr Samuels?"

WHAT IS HAPPENING?

The answer was hesitant. "Some kind of virus is blocking the signal. I am working to clear it. Please bear with me."

The avatar disappeared. Delilah thought, NO! But instantly the blackness began to recede. It slowly turned grey, and the lines of the Reading Room gradually became visible behind the reappearing windows of the operating system.

Delilah heaved a sigh of relief as she surfaced. Then a thought struck her, and she grasped one of the last wisps of blackness as it fled across the screen. It struggled for a moment, before dissolving into a few lines of glowing code in her hand.

Librarian? The avatar reappeared. "DrSamuels!" it said. "Nice to have you back with us.
Please accept the library's sincerest apologies." Not your fault. Do you recognize these? Delilah spread the code out on the screen. The bot touched it and made a face.

"Very unpleasant, Dr Samuels. Designed to be absorbed straight into your nervous system."

Through my socket?

"Probably, Dr Samuels. Nasty things, these custom viral patches. Tailored to your signature; could have sent you quite mad."

Is the maker's signature still on them? Do you recognize it?

"Yes, Dr Samuels. Here." The bot indicated a magenta aura around some of the letters. "Let me check my database. That is the marker of Dr Morgan Swift."

So. Swift fancied herself a bioware engineer. Well, Delilah knew something about that herself.

Librarian, can I see the server plan?

The bot gazed at her for a moment, then said: "I cannot allow that, Dr Samuels. But I must take myself and the security protocols offline temporarily for testing, following this upsetting incident."

It winked out, and a diagram flicked up. Thank heavens for woolly logic.

Delilah moved aside several layers of plan, until she reached the terminal connections. She followed a few threads, and finally found the magenta glow that matched the code. Swift was connected to a terminal in the corner. Delilah looked up through the interface; yes, there was that blonde head.

She pulled the virus up, and fiddled with the code for a while, adding a few personal touches. Then she looked back at the plan.

Swift was reading a book on medieval sorcery, but next in her queue was one on ancient Egyptian alchemy, the subject of the paper that Delilah had rejected. Perfect. Delilah slipped the code between its pages, then fled back to her own terminal.

Librarian?

The smiling face flicked up. "Hello, Dr Samuels. You will be pleased to hear that the system has been declared safe."

Oh good. Well, I must be going. But don't let anyone read the Leyden Manuscript before DrSwift, will you?

"Naturally not, Dr Samuels; it is locked to her queue. Goodbye, Dr Samuels!"

Delilah was out in the Euston Road before the screaming started.

Anna Novitzky tames words by day and lets them run free by night. 